\title{
A Case of Multiple Myeloma Presenting with Diabetes Insipidus
}

"Rudrajit Paul, ${ }^{1}$ Aditya V. Ruia, ${ }^{1}$ Asim Saha, ${ }^{1}$ Jayati Mondal, ${ }^{2}$ T. J. Sau, ${ }^{1}$ Indranil Thakur, ${ }^{1}$ Kunal Haldar ${ }^{1}$

$$
\text { حالة مايلوما متعددة تصاحب مرض السكري الكاذب }
$$

رودراجيت بول، أديتيا فيكرام رويا، عاصم ساهـا، جاياتي موندال، تي جى ساو، إندرانيل ثاكور، كونال هـالدار

ABSTRACT: Multiple myeloma ( $M M)$ can present with involvement of the central nervous system in the form of nerve palsy, plasma cell masses or, rarely, with endocrinological effects due to involvement of the pituitary gland. Usually, in such cases, the disease has a rapid progression and poor prognosis. We report a 52-year-old man who was admitted to the Kolkata Medical College, Kolkata, India, in 2016 with a prolonged low-grade fever and hypernatremia. Shortly afterwards, the patient began to complain of increased urinary frequency and drowsiness. The hypernatremia was treated with intranasal desmopressin and free water replacement. Serum protein electrophoresis and an immunofixation study revealed an immunoglobulin G-k monoclonal band. Magnetic resonance imaging of the pituitary gland revealed the absence of a posterior bright spot and spotty infiltration of the pituitary fossa. A bone marrow biopsy confirmed a diagnosis of cranial diabetes insipidus due to posterior pituitary MM infiltration.

Keywords: Multiple Myeloma; Diabetes Insipidus; Pituitary Gland; Hypernatremia; Case Report, India.

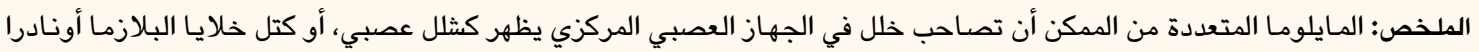

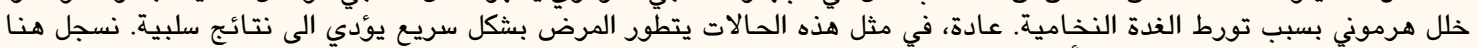

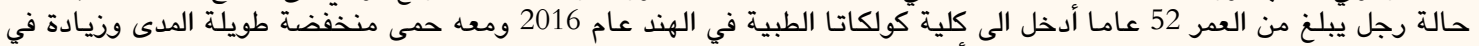

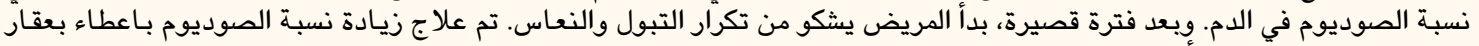

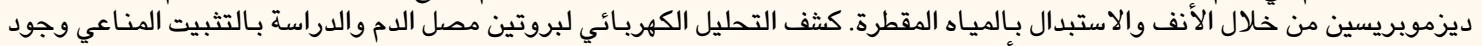

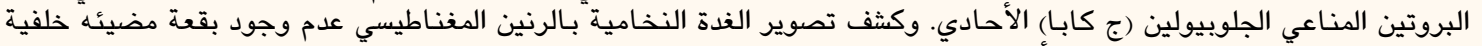

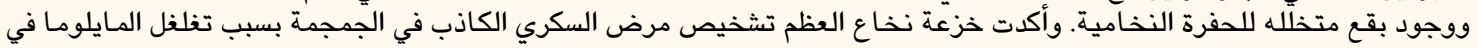

$$
\begin{aligned}
& \text { الغدة النخامية الخلفية. } \\
& \text { الكلمات المفتاحية: ميولوما متعددة؛ مرض السكري الكاذب؛ الغدة النخامية؛ ازدياد نسبة الصوديوم بالدم؛ تقرير حالة؛ الهند. }
\end{aligned}
$$

$\mathrm{M}$ Ultiple myeloma (MM) is a haematological malignancy of the plasma cells which can affect multiple organs; in cases of neurological involvement in MM, this may take different forms. ${ }^{1-3}$ While both the central and peripheral nervous systems may be affected, involvement of the central nervous system (CNS) is rare and the prognosis is usually quite poor. ${ }^{2}$ Usually, CNS involvement is observed in cases of established residual $\mathrm{MM}$ or during a subsequent relapse. ${ }^{3}$ This case report describes a patient with MM which manifested initially with cranial diabetes insipidus.

\section{Case Report}

A 52-year-old man was admitted to the Kolkata Medical College, Kolkata, India in 2016 with a low-grade fever of one month's duration. He had been treated several times for a recurrent respiratory tract infection over the previous month. Upon admission, a clinical examination revealed pallor and mild dehydration. There was no evidence of organomegaly, bone tenderness or lymphadenopathy. The patient had no urinary complaints and weighed approximately $61 \mathrm{~kg}$. As he had a fever with scattered crepitations in the chest cavity, he was initially treated for a respiratory tract infection. Initial blood investigations revealed haemoglobin levels of $6 \mathrm{~g} / \mathrm{dL}$, a total leukocyte count of 9,000/ $\mu \mathrm{L}$ (neutrophils: 59\%; lymphocytes: 30\%; eosinophils: $6 \%$ ) and a platelet count of $80,000 / \mu \mathrm{L}$. His erythrocyte sedimentation rate was $110 \mathrm{~mm}$ in the first hour and his urea and creatinine levels were $72.1 \mathrm{mg} / \mathrm{dL}$ and $1.6 \mathrm{mg} / \mathrm{dL}$, respectively. His serum albumin level was $2.9 \mathrm{~g} / \mathrm{dL}$, his globulin level was $10.4 \mathrm{~g} / \mathrm{dL}$ and his serum calcium level was $8.6 \mathrm{mg} / \mathrm{dL}$ (corrected: $9.5 \mathrm{mg} / \mathrm{dL}$ ). At admission, his blood serum sodium and potassium levels were $148 \mathrm{mEq} / \mathrm{L}$ and $4 \mathrm{mEq} / \mathrm{L}$, respectively.

On the second day following admission, the patient suddenly complained of increased urinary 


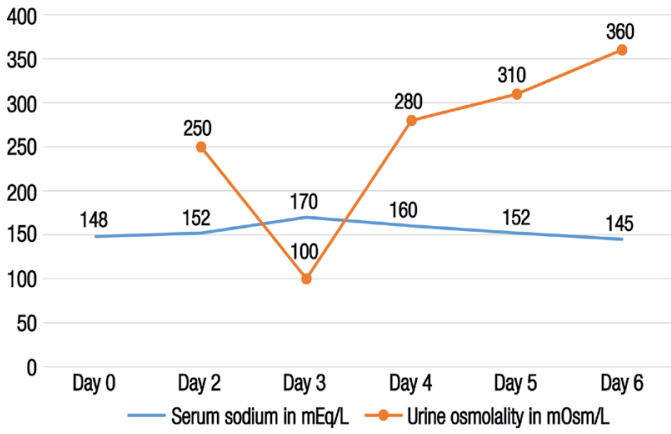

Figure 1: Line graph showing changes in the blood serum sodium levels and urine osmolality of a 52-yearold man with a prolonged low-grade fever and hypernatremia from the day of admission (Day 0) onwards. Intranasal desmopressin was administered from the third day onwards. The patient was subsequently diagnosed with diabetes insipidus.

frequency both during the day and at night. His total daily urinary output was approximately $9 \mathrm{~L}$ while drinking a normal amount of water ad libitum. His 24-hour urinary creatinine level was $1,100 \mathrm{mg}$ and urinary osmolality was $250 \mathrm{mOsm}$. There was no evidence of increased thirst and the patient was not currently taking any diuretics or mannitol. His blood and urine glucose levels were also normal. A microscopic analysis of a urine sample did not reveal any evidence of infection. By the third day of admission, the patient had become drowsy. His blood sodium level was $170 \mathrm{mEq} / \mathrm{L}$ and urine osmolarity was $100 \mathrm{mOsm}$. As a result, free water replacement was immediately initiated at $100 \mathrm{~mL} /$ hour. Following a desmopressin challenge as per standard protocols, a dose of 10 $\mu \mathrm{g}$ of desmopressin was administered intranasally thrice daily, as the intramuscular form of the drug was not available. Subsequently, the patient's blood serum sodium levels gradually fell from $160 \mathrm{mEq} / \mathrm{L}$ on day four to $152 \mathrm{mEq} / \mathrm{L}$ on day five and $145 \mathrm{mEq} / \mathrm{L}$ on day six [Figure 1]. His urinary output decreased to $5 \mathrm{~L} /$ day and then $3 \mathrm{~L} /$ day, respectively, on the first and second days after the administration of desmopressin. The patient's consciousness level also improved. His blood pressure remained normal throughout the admission period.

On the second day following admission, the patient underwent serum protein electrophoresis which revealed a monoclonal band in the $\gamma$-globulin region. According to an immunofixation study performed on day six, the monoclonal globulin was an immunoglobulin $G$ k-light chain. The patient's serum $\beta_{2}$-microglobulin level was $1,800 \mu \mathrm{g} / \mathrm{mL}$. Skeletal X-rays did not reveal any lytic lesions. A T1weighted magnetic resonance imaging (MRI) scan of the pituitary gland region on the seventh day revealed

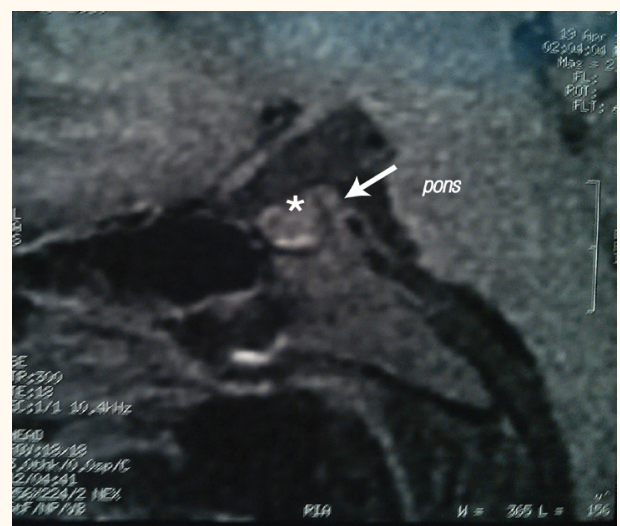

Figure 2: T1-weighted magnetic resonance imaging of a 52-year-old man with a prolonged low-grade fever and hypernatremia showing the absence of a posterior pituitary bright spot (arrow) with spotty infiltration of the pituitary fossa (asterisk), likely due to multiple myeloma.

the absence of a posterior pituitary bright spot along with some infiltrations, likely from the underlying malignancy [Figure 2]. Although a cerebrospinal fluid (CSF) analysis was performed twice (on days three and seven), no plasma cells were seen. Levels of plasma cortisol and thyroid-stimulating hormone were also normal.

A bone marrow biopsy performed on the $10^{\text {th }}$ day following admission showed approximately 30\% plasma cells with depressed erythropoiesis. The patient was thus diagnosed with MM and cranial diabetes insipidus due to posterior pituitary infiltration. A pituitary biopsy was not performed as the patient did not agree to the procedure. Additionally, in view of his severe dehydration and hypernatremia, a water deprivation test was not attempted, although the patient continued using an intranasal desmopressin spray. However, after being informed of the diagnosis, the patient refused further treatment and was subsequently lost to follow-up.

\section{Discussion}

In cases of MM, involvement of the CNS can manifest in different forms, including carcinomatous meningitis, cranial nerve palsy, quadriparesis or higher-function abnormalities such as dysphasia. ${ }^{3}$ These effects can occur as a result of the direct infiltration of the malignant plasma cells, the development of plasmacytomas in the skull or because of metabolic derangements caused by the malignancy. ${ }^{3}$ Generally, most patients with CNS myelomas have a very poor prognosis. ${ }^{3}$ It is postulated that malignant plasma cells acquire certain molecular characteristics which enable them to invade the CNS and which also confer drug resistance; hence, any form of therapy is largely ineffective. ${ }^{3}$ 
Usually, MM infiltrates the CNS via leptomeningeal spread; however, direct CNS involvement due to plasma cell deposit may rarely occur. ${ }^{5}$ In such circumstances, repeated CSF samples may be negative for plasma cells, as in the current case; Yi et al. reported a case of MM with brain parenchymal involvement from Korea wherein the frontal lobe space-occupying lesion was detected after a negative CSF analysis. ${ }^{5}$ However, adjacent bony destruction and other punched out lesions of the skull were also present, features which were not seen in the present case $^{5}$ In a report from Japan, Harada et al. described a 71-year-old male who was diagnosed with massive intracerebral plasma cell metastasis without skull involvement. ${ }^{6}$ Nevertheless, the cerebral metastasis occurred almost two years after the initial diagnosis of $\mathrm{MM}$; in the present case, the cerebral involvement was evident from first presentation. ${ }^{6}$ This may indicate that the patient in the current case had plasma cells with a de novo aggressive phenotype.

Diabetes insipidus in MM is very rare and can have several aetiologies. ${ }^{7,8}$ First, tubular toxicity due to excreted light chains may cause nephrogenic diabetes insipidus which is resistant to desmopressin, although potentially responsive to myeloma chemotherapy. ${ }^{7}$ In the current case, a diagnosis of nephrogenic diabetes insipidus was excluded as the patient was not currently taking drugs known to cause this condition and both his serum calcium and potassium levels were normal. Second, cranial diabetes insipidus may be caused by infiltration into the posterior pituitary region. Cranial diabetes insipidus is extremely rare in MM, with only two cases reported to date. ${ }^{8}$ In one of these cases, a plasma-cytoma of the sella turcica led to panhypopituitarism which did not respond to therapy. ${ }^{8}$ In the present case, there were no features of anterior pituitary dysfunction to suggest panhypopituitarism. In the other reported case of cranial diabetes insipidus, MM chemotherapy treatment led to a resolution of the diabetes insipidus-related symptoms. ${ }^{8}$

Additionally, MM has been associated with autoimmune phenomena. ${ }^{9}$ Thus, autoimmune involvement of the pituitary gland is theoretically a possibility; however, neural autoimmune phenomena are very rare. ${ }^{9}$ In addition, autoimmune hypophysitis usually involves the anterior pituitary first. ${ }^{10}$ However, in the present case, the patient's serum cortisol levels were normal. As such, autoimmune pituitary involvement was deemed unlikely to have caused the diabetes insipidus. Moreover, the rise in urine osmolality above 300 mOsm following the administration of desmopressin was deemed to further confirm a diagnosis of central cranial diabetes insipidus. ${ }^{4}$
Not all MM cases with pituitary masses are associated with diabetes insipidus. Mandagere et al. reported a 53-year-old woman with a sellar plasmacytoma which had only mass effects and no endocrine effects; this was resected completely with a relatively good outcome in which the patient remained diseasefree for the following seven years. ${ }^{11}$ In the present case, the presence of features of diabetes insipidus indicated extension of the tumour beyond the sella turcica and thus surgical resection was not feasible. Patients with both MM and diabetes insipidus generally have a poorer prognosis. ${ }^{5}$ One unusual feature of the present case was the absence of increased thirst at the onset of diabetes insipidus. This feature is very rarely reported and is often associated with increased mortality. ${ }^{12}$ In the present case, this may have been due to simultaneous damage to the hypothalamic thirst centre, although there was no evidence of this on MRI. Management of diabetes insipidus without increased thirst is more complex because patients require daily assessments to ensure adequate water intake. ${ }^{12}$

Although the present case report is limited by a lack of definitive evidence from a pituitary biopsy, a few other cases of MM with pituitary involvement have been reported in which the diagnosis was also made presumptively. ${ }^{8}$ Taking a biopsy sample from the posterior pituitary gland is a technically demanding procedure and often not feasible in certain institutions. A CSF analysis is an indirect method of diagnosing MM, especially to rule out alternative diagnoses like infection. ${ }^{3}$ However, in the present case, a repeated CSF analysis was normal.

\section{Conclusion}

This case report describes a patient with MM which manifested initially as cranial diabetes insipidus. In MM cases, involvement of the CNS is rare and generally has a very poor prognosis for affected patients; clinicians should therefore be aware of this potential manifestation. In addition, abnormally increased urinary output in a patient with MM should prompt investigations for concomitant diabetes insipidus.

\section{References}

1. Kashyap R, Kumar R, Kumar S. Cranial nerve palsy in multiple myeloma and solitary plasmacytoma. Asia Pac J Clin Oncol 2010; 6:251-5. doi: 10.1111/j.1743-7563.2010.01327.x.

2. Méndez CE, Hwang BJ, Destian S, Mazumder A, Jagannath S, Vesole DH. Intracranial multifocal dural involvement in multiple myeloma: Case report and review of the literature. Clin Lymphoma Myeloma Leuk 2010; 10:220-3. doi: 10.3816/ CLML.2010.n.035. 
3. Schluterman KO, Fassas AB, Van Hemert RL, Harik SI. Multiple myeloma invasion of the central nervous system. Arch Neurol 2004; 61:1423-9. doi: 10.1001/archneur.61.9.1423.

4. Barts Health NHS Trust Centre for Endocrinology. Barts endocrine e-protocols for pituitary function. From: www. bartsendocrinology.co.uk/resources/PITUITARY_Barts_ protocol_\$5Bfinal\$5D.pdf Accessed: Nov 2016.

5. Yi HJ, Hwang HS, Moon SM, Shin IY, Choi YH. A case of multiple myeloma with brain parenchyme involvement. Brain Tumor Res Treat 2013; 1:103-6. doi: 10.14791/btrt.2013.1.2.103.

6. Harada K, Yoshida J, Wakabayashi T, Sugita K, Ichihara M, Hotta T, et al. [A case of multiple myeloma with intracerebral metastasis]. No Shinkei Geka 1992; 20:1113-17.

7. Goranov S, Hristova I, Pencheva K. Nephrogenic diabetes insipidus: Prodromal phase of multiple myeloma. Folia Med (Plovdiv) 1994; 36:63-6.
8. Shand JA, McGrath N. Reversible diabetes insipidus in a patient with multiple myeloma. N Z Med J 2015; 128:52-4.

9. Shimanovsky A, Alvarez Argote J, Murali S, Dasanu CA. Autoimmune manifestations in patients with multiple myeloma and monoclonal gammopathy of undetermined significance. BBA Clin 2016; 6:12-18. doi: 10.1016/j.bbacli.2016.05.004

10. Dhanwal DK, Dharamshaktu P. Autoimmune hypophysitis. Indian J Med Res 2013; 137:995-6.

11. Mandagere KA, Schimke RN, Kyner JL, Bhatia PS. An unusual sellar mass: Solitary plasmacytoma. Endocr Pract 1998; 4:382-6. doi: 10.4158/EP.4.6.382

12. Eisenberg Y, Frohman LA. Adipsic diabetes insipidus: A review. Endocr Pract 2016; 22:76-83. doi: 10.4158/EP15940.RA. 